\title{
DERLEME/REVIEW
}

\section{GELENEKSEL VE TAMAMLAYICI TIP UYGULAMALARININ GÜLEN YÜZÜ: KAHKAHA YOGASI}

\section{Zülfünaz ÖZER ${ }^{1}$ (iD Sebahat ATEŞ ${ }^{2}$}

\begin{tabular}{ccc}
\hline Alınıs Tarihi/Received & Kabul Tarihi/Accepted & Yayın Tarihi/Published \\
21.12.2018 & 01.03 .2021 & 21.03 .2021 \\
\hline Bu makaleye atıfta bulunmak için/To cite this article: & \\
Özer Z, Ateş S. Geleneksel ve Tamamlayıcı Tıp Uygulamalarının Gülen Yüzü: Kahkaha Yogası. Anadolu \\
Hemşirelik ve Sağlık Bilimleri Dergisi, 2021; 24(1): 108-116. DOI: 10.17049 /ataunihem.500301 \\
\hline
\end{tabular}

\section{$\ddot{O} Z$}

Genellikle kahkaha, mutluluğun görsel bir şekilde anlatımı ya da sevinç duygusu olarak kabul edilmektedir. Gülmenin insan vücudunu fizyolojik ve psikolojik olarak olumlu yönde etkilediği bilinmektedir. Kahkaha yogasini, gevşeme ve nefes egzersizlerinin birleşmesinden oluşan nefes teknikleri ve koşulsuz kahkahadan oluşan egzersizler oluşmaktadır. Kahkaha yogası farklı hastalıklara (kanser, diyabetes mellitus vb) bağll ortaya çıkan semptomların şiddetinin azaltılmasinda ve mevcut durumun (stres) iyileştirilmesinde bir hemşirelik girişimi olarak uygulanabilmektedir. Sağllk alaninda oluşan teknolojik geliş̧meler ve bilgi artışl ile beraber hemşirelerin rol ve sorumluluklarında da değişiklikler olmuş, geleneksel ve tamamlayıcı tıbbın hemşirelik girişimi olarak uygulanabileceği bildirilmişstir. Kullanımı giderek yaygınlaşan ve etkileri kanıtlanan bir giriş̧im olan kahkaha yogasına iliş̧kin Türkiye'de yapılmış çok az çalışmaya ulaşıldd. Bu derlemede, kahkaha yogası ve etkileri hakkında sağlı profesyonellerini bilgilendirmek, kanıta dayalı uygulamalar çerçevesinde sağlığın geliştirilmesinde nasıl kullanılacağını anlatmak amaçlandı.

Anahtar kelimeler: Geleneksel ve tamamlayıcı tıp uygulamaları; Hemşirelik; Kahkaha yogası; Yoga.

\section{ABSTARCT}

The Small Face of Traditional and Complementary Medical Applications: Laughter Yoga

Laughter is usually acknowledged as a visual representation of happiness or feeling of joy. It is known that laughter positively effects human body physiologically and psychologically. Laughter yoga is an exercise composed of breathing techniques involving combination of relaxation and breathing exercises and unconditional laughter. Laughter yoga could be applied as a nursing intervention for decreasing severity of various disease (cancer, diabetes mellitus, etc.) symptoms and improving current condition (stress). Technological developments in health area and increased knowledge also changed the role and responsibilities of nurses; traditional and complementary medicine is reported as applications that can be used as nursing interventions. Laughter yoga application has been increasing and its effects are proven; however, there are only few studies on laughter yoga in Turkey in the literature. This review aimed to inform health professionals about laughter yoga and its effects, to represent how it could be used for improvement of health in context of evidence based practices.

Keywords: Traditional and complementary medical applications; Nursing; Laughter yoga; Yoga

\footnotetext{
${ }^{1}$ Sorumlu Yazar: İstanbul Sabahattin Zaim Üniversitesi, Sağlık Bilimleri Fakültesi, Hemşirelik Bölümü, (Dr. Öğr. Üyesi), ORCID: 0000-0002-2431-2346, e-posta: zulfinazozer@gmail.com

2 Maltepe Üniversitesi, Hemşirelik Yüksekokulu, (Dr. Öğr. Üyesi), ORCID: 0000-0002-8300-8037, e-posta: sebahatakbal@gmail.com
} 


\section{GİRIS}

Dünya Sağllk Örgütü'ne (DSÖ) göre; "geleneksel tıp uzun bir geçmişe sahiptir. Fiziksel ve ruhsal hastalıklardan korunma, bu hastalıklara tanı koyma, iyileştirme veya tedavi etmenin yanında sağlığın sürdürülmesinde de kullanılan, farklı kültürlere özgü teori, inanç ve tecrübelere dayal1- yapilabilen veya yapılamayan- bilgi, beceri ve uygulamalar bütünüdür". Bazı ülkelerde "tamamlayicı tıp" ya da "alternatif tıp" terimleri geleneksel tıp teriminin yerine kullanılmaktadır (1). "Alternatif tıp" genel olarak tıbbi tedavinin yerine kullanılan yöntemleri tanımlarken, "tamamlayıcı tıp" ise tıbbi tedavi ile birlikte kullanılan ya da tıbbi tedaviyi tamamlayan yöntemler (ağrıyı gidermede ilaç tedavisiyle birlikte hayal kurma, müzik dinleme ve gevşeme tekniklerinin kullanılması gibi) olarak tanımlanmaktadır. $\mathrm{Bu}$ tedavilerin tümü tamamlayıc1 ve alternatif tıp olarak adlandırılmaktadır (2).

Türkiye'de de "alternatif tıp" terimi uzun yıllar benzer anlamda kullanılmıș, fakat son yıllarda DSÖ başta olmak üzere uluslararası kuruluşların önerileri ve yapılan çalışmaların 1şı̆̆ında tamamlayıc1 ve alternatif tı kavramı yerine, "geleneksel ve tamamlayıc tip (GETAT)" kavramı kullanılmaya başlanmıştır. Sağlık Bakanlığı'nın, Ekim 2014 yılında yayımladığı "Geleneksel ve Tamamlayıcı Tip Uygulamaları Yönetmeliği”nde de bu şekilde ifade edilmiştir (1).

Akut ve kronik birçok hastalığın tedavisinde hastalar, yaşadıkları belirti ve bulguları hafifletmek veya gidermek için GETAT yöntemlerini kullanmaktadır. GETAT yöntemlerinin kullanımı tüm dünyada giderek yaygınlaşmaktadır. GETAT ile ilgilenen sağlık profesyonellerinin sayısının artamasinın da bu yöntemleri kullanan hasta sayısında artışı etkilediği bildirilmiștir. GETAT yöntemlerin klinik kullanımı ve diğer tedavi yöntemleriyle birlikte kullanımında meydana gelebilecek yararlı ve zararlı etkilerinin hastalara sürekli bakım veren hemşireler tarafından bilinmesi hasta güvenliği için önemlidir. GETAT'1 kullanan hasta ve yakınları bu uygulamalar konusunda çeşitli yollardan (internet, televizyon) bilgi edinmektedirler. Ancak yanlış ve eksik bilgilendirme ve bilinçsiz kullanımdan dolayı, hastaların tedavi programlarında aksamalar ya da istenmeyen sonuçlar meydana gelebilmektedir (3). Kullanılan GETAT yöntemleri ile ilaçlar arasında etkileşimler meydana geldiği ve etkileşimlerden dolayı oluşan yan etkiler organlarda fonksiyon bozukluklarına ve hastalık tablosunun ilerlemesine neden olduğu belirtilmektedir (4-6). Ayrıca kullanılan çeşitli bitkisel ürünlerin kanser ilaçlarının etkinliğini azaltabildiği veya yan etkilerini artırabildiği bildirilmektedir (5).

Türkiye'de genel hasta popülasyonunda GETAT kullanım oranının \%25.2-86.3 aralığında olduğu bildirilmiştir (7). Yapılan çalışmalarda da hemşirelerin çoğunluğunun GETAT uygulamalarına ilişkin bilgilerinin sınırlı olduğu, hasta ve hasta yakınlarını bu uygulamalar hakkında bilgilendirecek yeterli donanıma sahip olmadıkları saptanmıștır $(2,3)$.

Hemşirelik; bireyi ve aileyi bir bütün olarak ele alan, onlarla tedavi edici bir iletişim kuran ve bilimsel temelli bir bakım sunana bir meslek olduğu için sadece teknik işlemleri değil çok yönlü bakım vermeyi de kapsamaktadır. Sağlık alanında meydana gelen teknolojik gelişmeler ve bilginin artışı ile beraber hemşirelerin rol ve sorumluluklarında değişiklikler olmuş ve GETAT' in hemşirelik girişimi olarak uygulanabileceği bildirilmiştir. $\mathrm{Bu}$ doğrultuda GETAT' in kuramsal bilgi ve sorun çözme becerisine sahip hemşirelerin bağımsız rolleri arasında olduğu ve GETAT kullanımına ilişkin etkin stratejiler belirleyerek bütüncül bir yaklaşım ile hastaların ve ailelerin yaşam kalitelerini artırmaları beklenmektedir (8). Masaj, sıcak ve soğuk uygulama gibi uzun bir tarihi geçmişi olan GETAT yöntemlerinden bazıları temel hemşirelik bakım uygulamaları arasında yer almaktadır. Refleksoloji ve kahkaha yogası gibi bazı GETAT uygulamaları da özel eğitim gerektirmektedir (9).

\section{Kahkaha}

Genellikle kahkaha, mutluluğun görsel bir şekilde anlatımı ya da sevinç duygusu olarak kabul edilmekte; gıdıklanmak, komik bir olayı ve şakayı duymak gibi etkenler ile ortaya çıkmaktadır. Sosyal etkileşimlerde kişinin niyetini açıklanmasına ve sohbetlerde duygusallığın sağlanmasına da yardımcı olmaktadır. Kahkaha bulaşıcıdır, birey güldüğü zaman yanında bulunan kişi bu durumdan etkilenerek gülmeye başlamaktadır (10). Gülme, organizmada gözlemlenebilen ve yeri doldurulmaz sosyal işlevler katan evrensel bir olgu olarak bildirilmiştir (11). Henry Bergson, gülme olgusunu ele alırken "Gülme ne anlama gelir? Gücünün temelinde ne yatıyor? Bir soytarının yüz şaklabanlığı, bir nükte, bir vodvil yanılmacası, bir ince komedya sahnesi arasında ortak olan ne vardır acaba? Bunca değişik 
ürünlere kimi zaman nahoş, kimi zaman hoş kokular veren bu değişmez özü bize hangi damıtma işlemi sağlar? (12).

Gülmenin insanoğlunun varoluş sürecinin bir parçası olduğu ve ilkçağlarda keşfedildiği saptanmıştır. Özellikle Aristotales insanı kavramsallaştırırken gülen hayvan terimini kullanmış ve gülmeyi temel insani özelliklerin en önemlisi olarak vurgulamıştır (12). Darwin'in ilk insanlar olarak adlandırdığ 1 primatlar, şempanzeler ve orangutanlar basitçe gülümseyen davranışlarda bulunmuşlar ve dişlerini göstermişlerdir. Mc Hovec ilk insanların konuşmadan önce güldügünü öne sürmüş ve ilk insanların muhtemelen çatıştıkları kişilerin ya da düşmanlarının farklılıklarıyla alay ettiklerini ve onları taklit ettiklerini, zayıf yönleri ve çirkinlikleriyle eğlendiklerini iddia etmiştir. $\mathrm{Bu}$ bilgiler insanların ilk gülüşlerinin mimiklere dayalı, sözsüz ve taklitle oluştuğunu düşündürmektedir (13).

Gülme eyleminin ortaya çıkma aşamasında, insanlar nesneler arasında ilişki kurmakta, bu nesneleri diğerleri ile karşılaştırarak onlara belirli bir anlam yüklemektedirler. Tüm bunların bir araya toplanmasıyla rahatlama sağlanmaktadır (12). Gülmenin mekanizmasını açılamaya çalışan ortak bir teoriden söz edilmemektedir. Çünkü insan sadece mizaha değil, bir puzzle çözdüğünde, tehlikeli bir durumdan kurtulduğunda, oyun kazandığında, hayal kırıklığına uğradığında, umutsuz hissettiğinde, eski bir arkadaşı ile karşılaştığında, utandığında ya da sinirlendiğinde de gülmektedir. Gülmeyi açıklayamaya çalışan çok sayıda teori olmasına ragmen en önemlileri, uyumsuzluk teorisi, üstünlük teorisi, ve rahatlama teorisidir $(11,13)$.

Üstünlük teorisi; kişinin başkalarının talihsizliğine gülerek, kendi üstünlüğünü yansittığını varsayan bu teori Platon, Aristotales ve Hobbes' in çalışmalarında görülmektedir (11). Üstünlük teorisinde gülmenin temelini, ortaya çıkan komik bir durumu bireyler birbirlerine karşı zafer olarak görmektedir. Yani insanlar bir kişinin düştüğü komik duruma gülerken (yere düşen kişiye gülmek gibi), aslında üstünlük duygusuyla kendilerini o durumun dişında tutarak hareket ederler. Aristotales, gülmenin çirkin ve güçsüzlere karşılık doğduğunu söylemektedir. Birey kendi üstünlünlügü ile karşıdakinin zihinsel ve bedensel kusurlarını karşılaştırmaktadır (13).

Rahatlama teorisi; Sigmund Freud ve Harbert Spencer'in öncüsü olduğu bu teoriye göre, insanlarda bastırılmış ya da gizli kalmış şiddet eğilimi gülme yolu ile açığa çıkmaktadır. Daha çok baskıcı rejimlerde ortaya çıkan bu durum, kişilerin gülme yoluyla otoriteden intikam alacağını ifade etmektedir. Freud, gülme ileengellenen enerjinin ortaya çıkmasının düşünce enerjisini açığa çıkaracağını vurgulamaktadır (12).

Uyumsuzluk teorisi gülmenin, kişilerin normal zihinsel tepkileri ve beklentileri ihlal edildiği zaman ortaya çıktığını savunmaktadır. Uyumsuzluk teorisini ilk defa kullanan Beattie gülmeyi "aynı kabalı içindeki, uyumsuzluklardan doğduğu görünüyor" şeklinde ifade etmiştir (11). Uyumsuzluk teorisine göre, kişiler, mantıksı, münasebetsiz veya beklenmedik bir olayla karşılaştıklarında gülme meydana gelmektedir. Toplumsal kurallara veya beklentilere uyulmadığında bu durum ortaya çıkmaktadır (12).

Gülmenin iyileştirici gücü, özellikleri ve yapıs1 20. yy daanlaşılmıştır (13). Gelotoloji, gülümsemenin ve kahkahanın insan fizyolojisi üzerindeki etkilerini psikolojik ve fizyolojik açıdan inceleyen, yeni gelişmekte olan bir bilim dalıdır. Bir bilim dalı olarak Gelotoloji, Yunanca kökenli olup gülmek, kahkaha atmak anlamına gelen "gelo", geloto" kelimelerinden türemiş ve Stanford Üniversitesi'nden William F. Fry tarafından çalışma alanı olarak başlatılmıştır (14). Tarihte gülme, 13. yy.'da cerrahi müdahalelerde anestezi olarak kullanılırken, 16. yy.'da depresyonu tedavi etmek amacıyla kullanılmıştır. Ayrıca Ortaçağda gülmenin, sindirime yardımcı olduğu varsayıldığından saray soytarılarının soyluları yemek sirasında eğlendirdikleri bildirilmiştir. Yunanlıların hasta bireyleri tedavi etmek için komedyenleri hastanın evlerine göndermeleri ve Amerikan yerlilerinde hastaları iyileştirmek için kabile doktorunun maskaralık yapması da gülmenin sağlık açısından faydalı olduğunun uzun yıllardır bilindiğini göstermektedir $(13,14)$. Türk toplumunda kullanılan "Bir kahkaha bir kilo pirzolaya denktir" atasözü de gülmenin sağlık için faydalı olduğuna dair toplumsal farkındalığa işaret etmektedir.

\section{Kahkaha Yogası}

Bertrand Russell, "Gülmek en ucuz ve etkili harika bir ilaçtır. Kahkaha evrensel bir ilaçtır' diye belirtmiştir. 1980'li yıllardan itibaren gülmenin insan vücudunda fizyolojik ve psikolojik olarak olumlu etkilerinin olduğu bildirilmiştir (15). Ankilozan spondilit hastası olan Norman Cousins 1979'da yayınlanan "Anatomy of an Illness As perceived by the 
Patient: Reflections on Healing and Regeneration" kitabında düzenli olarak komik videolar izleyip, gülerek ağrısını azalttığını böylece daha kolay uyuyabildiğini vurgulamıştır (16). Gülme, gerginlik, kayg1, nefret ve öfke gibi olumsuz duyguları azaltmaya yardımcı olmakta, bireylerde stres ve depresyonu hafifleterek kişilerarası ilişkilerinin gelişmesine yardımc1 olamktadır (17). Bir kişiye, güldüğünde ne hissettiği sorulduğunda, kendisini rahatlamış, enerjik, mutlu ve mükemmel hissettiğini söylemektedir. Kişi kendisini, gülerken daha sağlıklı, az stresli, pozitif enerji yüklü, genç ve sakin hissetmektedir. Tüm bu olumlu duygular bireyin günlük hayatına olumlu olarak yansıyacak, bireyin toplumdan uzaklaşmasını engelleyecektir (13).

Kahkaha, trakeanın açılması, epiglottisin larinksi daraltması ve ses tellerinin titremesiyle oluşmakta ve kahkaha sırasında gözyaşı bezleri refleks olarak gözleri 1slatmaktadır (18). Yapılan görüntüleme çalışmalarında, kahkaha sırasında beynin amigdala, hipotalamus, temporal ve serebellar bölgeler gibi çeşitli bölgelerinin aktif çalıştığı saptanmıştır (19). Limbik sistemde hipokampus ve amigdalanın kahkahaya katıldığ belirtilmiştir (10). Nörobilim Derneği, kahkahaların nöral kontrolünü üç bileşene ayırmıştır: bilişsel alan, motor alan ve duygusal alan. Bilişsel alan veya frontal korteks, çeşitli uyaranları almakta; motor alan, kahkaha sirasında mimik oluşturmak için gerekli olan bir dizi kas hareketi üretmekte; duygusal alan olarak tanımlanan nükleus accumbens ise, mutluluğu rasyonalize ettietmektedir (20). Kahkahanın kas, kardiyovasküler, solunum, endokrin, immün ve santral sinir sistemi üzerinde olumlu etkileri bulunmaktadır (17) (Tablo 1).

Tablo 1. Kahkahanın Fizyolojik ve Psikolojik Etkileri

\section{Fizyolojik Sonuçlar}

- Egzersiz yapar ve kasları rahatlatır.

- Solunumu iyileştirir.

- Dolaşımı hızlandırır.

- Stres hormonlarını azaltır.

- Bağışıklık sistemini güçlendirir.

- Ağr1 eşiğini ve ağrıya tolerans1 artırır.

- Zihinsel işlevi artırır.

\section{Psikolojik Sonuçlar}

- Stres, anksiyete ve gerginliği azaltır, depresif duyguları azaltır.

- Ruhsal iyiliği, benlik saygısını, umudu, enerji ve canlılığı arttırır.

- Bellek ve yaratıcı düşünmeyi geliştirir.

- Kişilerarası etkileşimi geliştirir.

- Dostluğu ve yardımseverliği artırır.

- Psikolojik sağlığı destekler.

- Yaşam kalitesini artırır.

- Neşeyi yoğunlaştırır ve bulaşıcıdır.
Dr. Madan Kataria, kahkahanın kardiyovasküler etkilerinin birçok düzenli aerobik aktiviteden daha güçlü olduğunu tanımlamıştır (20). Kahkaha ile vasküler sistem arasındaki bağlantı ilk kez 2005 yılında Maryland Tip Merkezi'ndeki araştırmacılar tarafindan saptanmıştır. Kahkahanın kan damarlarının iç yüzeyinde bulunan, endotelde dilatasyon yaptığı ve kan akımının arttığı bildirilmiştir. William Fry (Stanford Üniversitesi) ve Dr. Michael Miller (Maryland Üniversitesi) hipotalamustan salınan beta-endorfinin endotel yüzeyinde yer alan reseptörleri aktive etmesiyle nitrik asit salgılandığını ve bunun sonucunda damarlarda vazodilatasyon geliştiğini saptamışlardır. Nitrik oksit ayrica inflamasyonu ve trombosit agregasyonunu azaltarak da kardiyovasküler sistemi korumaktadır (18). Maryland Üniversitesi'ndeki kardiyologlar, miyokard enfarktüsü (MI) geçiren hastaların \% 40 daha az güldüğünü belirlemişler ve kahkahanın MI'ya karş1 koruyucu olduğunu bildirmişlerdir (20). Kahkahanın aynı zamanda; kan basıncını düşürdüğüe kandaki oksijen miktarını arttırdı̆̆g; kas tonusünü azalttı̆̆ı; büyüme hormonu, betaendorfin ve melatonin salınımını arttırdı $\breve{g}$; bağışıklık sistemini güçlendirdiği, bağışıklık sisteminde fagositoz sürecini kolaylaştırdığ aynı zamanda vücudun enfeksiyonlarla mücadelesine (serum IgA ve IgG düzeylerinde, T lenfositlerinin sayısında ve interferon-gamma düzeylerinde artış) yardımcı olduğu; astımlı hastalarda bronş duyarlılığını azalttığı, Kronik Obstrüktif Akciğer hastalarında inflamasyonu azalttığ1; atipik dermatitli hastalarda spesifik IgE üretimini azalttığ1 ve serum nörotin düzeylerini düşürdüğü bildirilmiştir $(16,18,20)$.

Psikiyatrist Robert Holden'den aktarıldığına göre, sahte kahkahaya vücudun gerçekmiş gibi tepki verdiğini, kahkaha ile üretilen gözyaşlarının, vücudun kahkahaya tepki olarak atmaya çalıştığı toksinleri içerdiği için 
üzüntü ve depresyonda üretilen gözyaşından farklı olduğu bildirilmiştir. Kahkaha yogasının, tüm iç organlara iyi mesaj gönderdiği, stres hormonu seviyelerini düşürdüğü, dolaşımı arttırdığ 1 ve kasları gevşettiği belirtilmiştir (21).

Kahkahanın, beta endorfin hormonunu üreten alt ön lob korteksi aktive ettiği böylece bireylerde zihinsel ve fiziksel rahatlama sağlayarak ağrı eşiğini yükselttiği bildirilmiştir (18). Vücutta doğal morfin olarak bilinen beta endorphin, merkezi sinir sisteminde ve nosiseptör yüzey membranında yer alan opioid reseptörlerine bağlanarak analjezik etki sağlamaktadır (22). Cousins kendi deneyimlerine dayanarak, kronik bir hastalığın üstesinden gelmek için kahkahayı terapötik bir müdahale olarak tanımlayan ilk kişidir ve 10 dakikalık kahkahanın, on iki saat boyunca ilaçsız ağrı kesici etki gösterdiğini ileri sürmüştür (23).

Bir GETAT yöntemi olan yoganın uyku kalitesi, gevşeme, yaşam tarzı ve yaşam kalitesi değișikliklerine olumlu etkileri olduğu bilinmektedir (24). Yoga türlerinden biri olan Kahkaha Yogası Hindistanlı hekim Dr. Madan Kataria tarafından 1995 yılında geliştirilmiş olup her bir seans; nefes egzersizleri, germe-gevşeme teknikleri ve kahkaha egzersizlerinden oluşmaktadır (25). Dr. Kataria Kahkaha yogasının dört aşamadan meydana geldiğini bildirmiştir. $\mathrm{Bu}$ aşamalardan ilki el çırpma ve 1sınma egzersizleri daha sonraki aşamayı derin nefes egzersizleri oluşturmaktadır. Ǘçüncü aşamada çocuksu oyunculuk aşamasına geçilmekte, son aşamada ise gülme egzersizleri yer almaktadır (26). Kahkaha yogası oturumları, germe ve esneme hareketleri, alkışlar, şarkılar ve vücut hareketlerini içeren hafif isınma teknikleri ile başlamaktadır. Bunlar her türlü engelleri yıkarak çocuksu oyun oynama duygularını geliştirirken nefes egzersizleri akciğerleri gülmeye hazırlayarak sonrasında bir dizi gülme egzersizleri ile birleştirilmektedir (15). Kahkaha yogas1 egzersizleri sırt üstü yatılarak ve dizleri tutup karına çekilerek de yapılabilmektedir (27). Kahkaha yogasında gülme, fiziksel bir egzersiz olarak başlayıp grupta bulunan diğer üyelerle göz teması sağlayarak onlarla çocuksu oyunlar oynayarak uyarılmaktadır. Bu uyarının çoğu zaman gerçek ve bulaşıcı bir gülmeye dönüştüğ̈̈; vücudun gerçek ve gerçek olmayan gülmeyi ayırt edemediği düşünülmektedir (24).

Kahkaha yogasının süresi minimum 20 dakika, maksimum 2 saat olup, haftada 2 seans olmak üzere en az 8 hafta uygulanmas1 önerilmektedir. Terapötik etkinin ilk 8 haftadan sonra bireysel düzeyde değerlendirilmesi gerektiği (16) ve yirmi dakikalık kahkaha dolu bir seansın fizyolojik yararlar sağlamak için yeterli olduğu bildirilmiş̧ir (18). Kahkaha yogasında, grup dinamiğini sağlayabilmek için grubun en az 5-15 kişiden oluşması önerilmektedir (24). Yapılan çalışmalarda kahkaha yogasının genellikle haftada bir ya da iki kez $1 ; 4,8$ ve 12 seans șeklinde uygulandığ 1 ve her bir seansın genellikle 30-45 dakika sürdüğü belirlenmiştir (10). Literatürde kahkaha yogasından 30-45 dakika sonra bile fizyolojik değișikliklerin ve rahatlamanın devam ettiği bildirilmiştir (28). Kahkaha yogası sadece Kahkaha Yogası sertifikası almış kişiler tarafindan uygulanabilmektedir. Kahkaha yogasinda uygulayıcının rolü oldukça önemlidir. Uygulayıc1, oturumu kontrol ederek seans1 başlamak için komut vermektedir. Yapılacak egzersizleri açıklayarak tanımlamakta, uygulayıcı grup dinamizmi için seansı başlatmakta ve sonlandırmaktadır. Uygulayıc1 oturumu sonlandirdıktan sonra geri bildirimler almalı ve sonraki oturumlar için bu geri bildirimleri değerlendirmelidir (11).

\section{kullanımı}

Kahkaha yogasının sağlık alanında

Kahkaha yogası ile yapılan çalışmaların çoğunluğunun, randomize kontrollü çalışmalar olduğu belirlendi. Çalışmalar daha çok yaşlı bireylerde yapılmış ve uygulamanın kronik hastalıklarda fiziksel ve psikolojik etkileri araştırılmıştır. Haftada iki kez 60 dakikalık toplam dört seans kahkaha yogası uygulanan postpartum dönemdeki 38 kadının immün yanitının ( $\operatorname{sgA}$ ) kontrol grubundakilere göre anlamlı olarak arttığı belirlenmiştir (29). Park (2013), depresif ve uyku bozukluğu olan yaşlı bireylerde haftada bir kez sekiz hafta uygulanan kahkaha yogasının depresyon skorlarını düşürdüğünü ve uyku kalitesini pozitif etkilediğini saptamış; depresyon ve uykusuzluğu iyileştirmek için kahkaha yogasının etkili bir hemşirelik müdahalesi olabileceğini belirtmiştir (30). Benzer bir çalışmada da, kahkaha yogasının yaşlı bireylerde depresyonun etkilerini azaltmada ve uyku kalitesini artırmada yararalı olduğu; yaşlilarda depresyon, ve uykusuzluk tedavisinde kullanılabilecek yararl1, maliyet-etkin ve kolay erişilebilir bir uygulama olduğu bildirilmiştir (31). Yaşl 1 bireylere haftada $2 \mathrm{kez} 5$ hafta uygulanan kahkaha yogasının, sosyal ve duygusal yalnızlı skorları ile ağrı skorlarını kontrol grubuna göre anlamlı olarak düşürdüğü bildirilmiştir (24). Yaşlı bakımı evinde yaşayan 
28 yaşlı bireye 6 hafta boyunca haftada bir kez 30 $\mathrm{dk}$ kahkaha yogası uygulanmıs, uygulama sonrası (1., 3. ve 6. seanslar) mutluluk puanlarında artış, olumlu ve olumsuz duygu durum puanlarında (3. ve 6. seans) azalma ve sistolik kan basincinda (1. ve 6. seans) düşüş saptanmıştır (32). Yapılan sistematik derlemede, kahkaha yogasının yaşlı bireylerde fiziksel sağlık (kan basınc1, kortizol düzeyi, uyku kalitesi) ve psikososyal sağlık (yaşam doyumu, yaşam kalitesi, yalnızlık, ölüm kaygıs1, depresyon, ruh hali, mutluluk) sonuçları üzerinde olumlu bir etkisi olduğu bildirilmiștir (33).

Kahkaha yogası ve grup egzersiz terapisinin karşılaştırıldığı bir çalışmada, her iki müdahalenin depresyonu iyileştirmede etkili olduğu, ancak kahkaha yogasının yaşam doyumunu iyileştirmede daha etkili olduğu saptanmıştır (27). Haftada $2 \mathrm{kez}$ (8 seans) $40 \mathrm{dk}$ yapılan kahkaha yogasının bireylerin depresyon puanlarını düşürdüğü ve uyku kalitesini geliştirdiği saptanmıştır. Kahkahanın, stres gibi olumsuz durumları kontrol etme ve depresyon gibi olumsuz duyguları olumlu duygulara dönüştürme yeteneğini arttırdığı bildirilmiștir (34). Kahkaha yogasının meme kanseri tedavisi sonras1 rehabilitasyon aşamasında hastaların yaşam kalitesini arttırdığ 1 bildirilmiştir (35). Diyabetes Mellituslu bireylerde yapilan çalışmada da postprandiyal kan glikozundaki artış1 azalttı̆ğ saptanmıştır (36). İran'da diyabetli öğretmenler ile yapılan çalışmada da, kahkaha yogasının ruh sağlığını iyileştirdiği ve yaşam kalitesini artırdı ̆̆ 1 bildirilmiştir (37).

Osteoartiritli bireylerde kahkaha yogasının, ağrı ve depresyon skorlarını azaltmada ve yaşam kalitesini iyileştirmede etkili bir müdahale olduğu ve osteoartritli bireylerin bakımında kullanılabilecek bir hemşirelik girişimi olduğu bildirilmiştir (38). Yapılan farklı bir çalışmada, kronik kas iskelet ağrıs1 olan hastalarda \%55 oranında ağrıyı azalttığı saptanmıştır (16). Yaşlı bakım evinde kalan bireylerle yapılan bir çalışmada, kahkaha yogasının ağnı puanını anlamlı olarak azalttığı belirtilmiştir (11). Ağrı, depresyon ve uyku kalitesinin incelendiği bir çalışmada ise kahkaha yogasının her üç parametreyide pozitif etkilediği belirlenmiştir (39).

Hemodiyaliz (HD) hastaları için kahkaha yogasının başarılı bir şekilde uygulanabilecek intradialitik fiziksel aktivitenin güvenli bir formu olduğu bildirilmiştir (40). Ayrıca kahkaha yogasının HD hastalarında ağrı, anksiyete, stres, depresyon ve yorgunluğu azaltmak; bağışıklığı, yaşam kalitesini, mutluluğu ve uyku kalitesini artırmak için önerilebileceği belirtilmiştir (41). Koreli HD hastalarına uygulanan kahkaha yogasının, ruh hali ve yaşam kalitesi (semptomlar, sosyal etkileşim kalitesi, fiziksel sağlığa bağlı rol kısitlamaları, duygusal iyilik hali) üzerinde olumlu etkiler sağladığı fakat kortizol seviyelerinde herhangi bir değişim oluşturmadığ saptanmıştır (42).

Organ nakli bekleyen hastalara uygulanan 20 dakikalık kahkaha yogasının (4 hafta) klinik sonuçlarının değerlendirildiği çalışmada; hastalarda ruhsal iyilik halinin (canlilik ve aktivite) arttığ 1 anksiyete ve depresyon puanlarının ve kalp hızının azaldığı bildirilmiştir (43). Cha ve Hong'un (2015) yaptıkları çalışmada, uygulamanın beşinci seansında özellikle ciddi depresif hastalarda depresyon puanlarında düşüş gözlenmiş, 10.seansta da serotonin düzeyinde artış ve depresyon puanlarında azalma saptanmıştır (44). İrritabl bağırsak sendromu olan hasatalara uygulanan 60 dakikalık (7 seans) kahkaha yogasının, hastaların yaşadıkları gastrointestinal semptomları azaltığ ve hastaların yaşam kalitesini iyileștirmede antianksiyete ilaçlarından daha etkili olduğunu belirtilmiştir (45).

Kemoterapi öncesi uygulanan kahkaha yogasının kanser hastalarında, zihinsel ve fiziksel rahatlama ile stresi azaltmada önemli bir rol oynayabileceği ifade edilmiştir (46). Terapötik bir kahkaha programının meme kanserli hastaların anksiyete, depresyon ve stres düzeyi üzerine etkisinin incelendiği bir çalışmada; müdahale grubunun kontrol grubuna göre anksiyete, depresyon ve stres puanlarının anlamlı olarak daha düşük olduğu bulunmuştur. Kahkaha yogasının etki mekanizması iyi anlaşılmamış olsa da, araştırmacılar gülmenin nöroendokrin ve stresle ilişkili hormonların salınımını azaltarak, hastalarda mevcut psikolojik stresi en aza indirdiğini vurgulamışlardır (47).

Kahkaha yogasının parkinsonlu hasta ve bakım verenlere etkisinin değerlendirildiği çalışmada; iyi olma ölçütlerini içeren sorulara (coşku, enerji seviyesi, ruh hali, iyimserlik, stres düzeyi gibi) şimdi nasıl hissediyorsunuz sorusuna her iki grupta yer alan katılımcilar iyi hissettiklerini ifade etmişlerdir (48). HIV'li hastalara bakım verenler hasta yakınları ile yapılan araştırmada, anksiyete ve depresyon gibi olumsuz duygularla baş edebilmek ve psikolojik iyi oluşu teşvik etmek için kahkanın düşük maliyetli bir müdahale olduğu bildirilmiştir. Kahkaha seanslarına günlük katılan bakım 
vericilerin, depresyon, anksiyete ve stres düzeylerinin azaldığı, sosyal ilişkilerinin ve baş etme stratejilerinin geliştiği, seanslar sonrasında rahatlama hissettikleri saptanmıştır (23).

Sağlıklı üniversite öğrencilerinde kahkaha yogasına bağl kortizol ve dehidroepiandrosteron (DHEA) seviyeleri ve kortizol/DHEA (C/D) oranlarında değişimin olup olmadığının incelendiği çalışmada, uygulama sonrası müdahale grubunda kortizol düzeyleri ve $\mathrm{C} / \mathrm{D}$ oranlarının anlamlı olarak azaldığı belirtilmiştir (49). Yapılan bir pilot çalışmada da sağlıklı bireylerde uygulanan kahkaha yogasinın 4.seansında kortizol seviyelerinde düşüş olduğu ve uygulamanın stres yönetiminde etkili bir müdahale olduğu bildirilmiştir (50).

Kahkaha yogasının hemşirelik öğrencilerinin genel sağlığ üzerinde olumlu etkisi olduğu; fiziksel iyi oluş ve uyku bozukluklarının belirtilerini iyileştirdiği, kaygı ve depresyon puanlarını azaltığı ve sosyal işlevleri geliştirdiği belirlenmiştir (25). Hemşirelik Bölümü 1. sınıf öğrencilerine uygulanan kahkaha yogasının yaşanan ruhsal belirtileri (anksiyete, depresyon, olumsuz benlik, somatizasyon) ve tükürük kortizol seviyesini azaltmada etkili bir hemşirelik girişimi olduğu bildirilmiştir (51).

Sağliklı bireylerde iş stresi üzerine kahkaha yogasının etkisinin değerlendirildiği randomize kontrollü çalışmada, uygulamanın kan basıncını ve kortizol düzeyini anlamlı olarak düşürdüğü

\section{KAYNAKLAR}

1. Mollahaliloğlu S, Uğurlu FG, Kalayci M, Öztaş D. Geleneksel ve tamamlayıcı tıp uygulamalarında yeni dönem. Ankara Medical Journal 2015;15(2): 102-5.

2. Çevik K, Bolsoy N, Beler M. Hemşirelerin tamamlayıcı ve alternatif tedaviye ilişkin bilgi ve görüşleri. Uluslararası Hakemli Hemşirelik Araştırmaları Dergisi 2016;6(1):1-15.

3. Lafçi D, Kaşıkçı MK. Yataklı sağlık kuruluşunda görev yapan sağlık personelinin tamamlayıcı ve alternatif tedavi yöntemlerini bilme ve kullanma durumları. Gümüşhane Üniversitesi Sağlık Bilimleri Dergisi 2014;3(4):1114-31.

4. Adibelli Z, Dilek M, Akpolat T. Lemon juice as an alternative therapy in hypertension in Turkey. International journal of cardiology 2009;135(2):e58-e9.

5. Tıbbi Onkoloji Derneği. Tıbbi Onkoloji Derneğinin Kanser Alanında Tamamlayıcı ve Alternatif Tedavilere Bakışı [internet]. 2020. [Erişim tarihi 23.02.2021]. http://www.kanser.org/toplum/?action=sayfa\&id $=2$. saptanmıştır (15). Supekar ve arkadaşları (2014), oluşturulacak kahkaha kulüplerinin esneklik ve yaşam kalitesi (fiziksel bileşen) açısından, toplumda sağlığın teşviki konusunda önemli bir rol oynadığını bildirmişlerdir (52).

\section{SONUÇ VE ÖNERILLER}

Kahkaha yogası maliyet-etkin ve kolay erişilebilir bir müdahale olarak sağllğ 1 geliştirmek, hastalıkla başa çıkmak ve fiziksel/duygusal ağrı veya stresten kurtulmak için uygulanabilecek bir GETAT yöntemidir. Kahkaha yogasının, fiziksel ve psikososyal sağlık üzerine yarattığı olumlu etkiler hasta-hemşire etkileşimi açısından oldukça önemlidir. Hemşireler bakımda kanıta dayalı kahkaha yaklaşımını benimsemeli ve hemşirelik uygulamalarına entegre edilebilmelidir. Hemşirelik alanında kahkaha ile ilgili kanıta dayalı araştırmalar yetersizdir. Kahkaha yogası uygulamasının farklı hasta gruplarında fizyolojik, psikolojik etkilerini inceleyen randomize kontrollü çalışmaların yapılması önerilmektedir. Sağlık kurumlarında kahkaha kulüpleri kurulması, hastalar için kahkaha yogası seansları düzenlenmesi önerilmektedir.

Çıkar çatışması: Çalışmada herhangi bir çıkar çatışması yoktur.

Yazar Katkısı: Fikir sahibi: Z.Ö., S.A; Kaynak taraması: Z.Ö.; Makalenin yazılması: Z.Ö., S.A.; Eleştirel inceleme: S.A.

6. Türk N, Süner A. Hipertansif olgularda nonfarmakolojik yöntem ve antihipertansif ilaç kullanımının analizi. Göztepe Tıp Dergisi 2008;23(4):133-42.

7. Doğan B, Karabudak Abuaf Ö, Karabacak E. Tamamlayic1/Alternatif Tip ve Dermatoloji. Archives of the Turkish Dermatology \& Venerology/Turkderm 2012;46(2):62-6.

8. Turan N, Öztürk A, Kaya N. Hemşirelikte yeni bir sorumluluk alanı: tamamlayıc1 terapi 2010; 3(1):103-8

9. Çevik K. Hemşirelikte Tamamlayici Ve Alternatif Tedavi: Refleksoloji. Ege Üniversitesi Hemşirelik Fakültesi Dergisi 2013;29(2):71-82.

10. Kin ÖK, Yildirim Y. Kahkaha Terapisi ve Sağlik Alanında Kullanım Örnekleri. Anadolu Hemşirelik ve Sağlı Bilimleri Dergisi 2017;20(1):63-6.

11. Kuru N, Kublay G. The effect of laughter therapy on the quality of life of nursing home residents. Journal of clinical nursing 2017;26(21-22):335462.

12. Fırat T. Dijital mizahın biçim bozumu: Bobiler. org örneği. Tarih Okulu Dergisi 2016;641-55. 
13. Yardımcı İ. Mizah kavramı ve sanattaki yeri. Uşak Üniversitesi Sosyal Bilimler Dergisi 2010;3(2):141.

14. Savage BM, Lujan HL, Thipparthi RR, DiCarlo SE. Humor, laughter, learning, and health! A brief review. Advances in physiology education 2017; 41:341-7.

15. Nagendra H, Chaya M, Nagarathna R, Kataria M, Manjunath M, Raghavendra R. The efficacy of Laughter Yoga on IT professionals to overcome professional stress. Laughter Yoga International: Mumbai, India. 2007.

16. Mora-Ripoll R. The therapeutic value of laughter in medicine. Alternative Therapies in Health \& Medicine 2010;16(6):56-64.

17. Yim J. Therapeutic benefits of laughter in mental health: a theoretical review. The Tohoku journal of experimental medicine 2016;239(3):243-9.

18. Satish P. Laughter therapy. . Journal of Pharmaceutical and Scientific Innovation 2012;1(3):23-4.

19. Nasr SJ. No laughing matter: Laughter is good psychiatric medicine. Current Psychiatry 2013;12(8):20-5.

20. Hasan H, Hasan TF. Laugh yourself into a healthier person: a cross cultural analysis of the effects of varying levels of laughter on health. International Journal of Medical Sciences 2009;6(4):200-11.

21. Sayed M, Gandham S. Effectiveness of Laughter Therapy on the Levels of Anxiety and Depression among Inmates Residing at An Old Age Institution: An Interventional Research. International Journal Of Scientific Research 2018;7(1):282-5.

22. Cabığlu M. Akupunktur ve Nörotransmitterler. Genel Tip Dergisi 2008;18(2):93-8.

23. Hatzipapas I, Visser MJ, van Rensburg EJ. Laughter therapy as an intervention to promote psychological well-being of volunteer community care workers working with HIV-affected families. SAHARA-J: Journal of Social Aspects of HIV/AIDS 2017;14(1):202-12.

24. Kuru Alıcı N, Zorba Bahceli P, Emiroğlu ON. The preliminary effects of laughter therapy on loneliness and death anxiety among older adults living in nursing homes: A nonrandomised pilot study. International journal of older people nursing 2018;13(4):e12206.

25. Yazdani M, Esmaeilzadeh M, Pahlavanzadeh S, Khaledi F. The effect of laughter Yoga on general health among nursing students. Iranian journal of nursing and midwifery research 2014;19(1):36-40.

26. Kataria M. Laugh for No Reason (2011 version). . Madhuri International: Lokhandwala Complex; 2011.

27. Shahidi M, Mojtahed A, Modabbernia A, Mojtahed M, Shafiabady A, Delavar A, et al. Laughter yoga versus group exercise program in elderly depressed women: a randomized controlled trial. International journal of geriatric psychiatry 2011;26(3):322-7.

28. Bennett MP, Lengacher C. Humor and laughter may influence health: III. Laughter and health outcomes. Evidence-based complementary and alternative medicine 2008;5(1):37-40.

29. Ryu KH, Shin HS, Yang EY. Effects of laughter therapy on immune responses in postpartum women. The Journal of alternative and complementary medicine 2015;21(12):781-8.

30. Park E. Effects of visiting laughter therapy on depression and insomnia among the vulnerable elderly. Journal of Korean Academy of Community Health Nursing 2013;24(2):205-13.

31. Ko HJ, Youn $\mathrm{CH}$. Effects of laughter therapy on depression, cognition and sleep among the community-dwelling elderly. Geriatrics \& Gerontology International 2011;11(3):267-74.

32. Ellis JM, Ben-Moshe R, Teshuva K. Laughter yoga activities for older people living in residential aged care homes: A feasibility study. Australasian journal on ageing 2017;36(3):E28-E31.

33. Alici NK, Donmez AA. A systematic review of the effect of laughter yoga on physical function and psychosocial outcomes in older adults. Complementary Therapies in Clinical Practice 2020:41:101252.

34. Han JH, Park KM, Park H. Effects of laughter therapy on depression and sleep among patients at long-term care hospitals. Korean Journal of Adult Nursing 2017;29(5):560-8.

35. Cho E, Oh H. Effects of laughter therapy on depression, quality of life, resilience and immune responses in breast cancer survivors. Journal of Korean academy of nursing 2011;41(3):285-93.

36. Čokolič M, Herodež ŠS, Sternad S, Krebs S. The inhibitory effect of laughter yoga on the increase in postprandial blood glucose in type 2 diabetic patients. Diabetol Croat 2013;42(2):54-8.

37. Heidary E, Shirazi M, Sanaguye MGR. The effectiveness of laughter yoga yraining on guality of life and mental health of women with diabetes. 2020;1(3):4-22.

38. Ko YJ, Hyun MY. Effects of Laughter Therapy on Pain, Depression, and Quality of Life of Elderly People with Osteoarthritis. Journal of Korean Academy of Psychiatric and Mental Health Nursing 2013;22(4):359-67.

39. Lee K-I, Eun Y. Effect of laugher therapy on pain, depression and sleep with elderly patients in long term care facility. Journal of muscle and joint health 2011;18(1):28-38.

40. Bennett PN, Parsons T, Ben-Moshe R, Neal M, Weinberg MK, Gilbert $\mathrm{K}$, et al. Intradialytic Laughter Yoga therapy for haemodialysis patients: a pre-post intervention feasibility study. BMC complementary and alternative medicine 2015;15(1):1-7.

41. Bennett PN, Parsons T, Ben-Moshe R, Weinberg M, Neal M, Gilbert K, et al., editors. Laughter and 
humor therapy in dialysis. Seminars in dialysis 2014;27(5):488-93.

42. Heo EH, Kim S, Park H-J, Kil SY. The effects of a simulated laughter programme on mood, cortisol levels, and health-related quality of life among haemodialysis patients. Complementary therapies in clinical practice 2016;25:1-7.

43. Dolgoff-Kaspar R, Baldwin A, Johnson MS, Edling N, Sethi GK. Effect of laughter yoga on mood and heart rate variability in patients awaiting organ transplantation: a pilot study. Alternative therapies 2012;18(4):53-8.

44. Cha MY, Hong HS. Effect and Path Analysis of Laughter Therapy on Serotonin, Depression and Quality of Life in Middle-aged Women. Journal of korean academy of nursing 2015;45(2):221-30.

45. Tavakoli T, Davoodi N, Tabatabaee TSJ, Rostami Z, Mollaei H, Salmani F, et al. Comparison of laughter yoga and anti-anxiety medication on anxiety and gastrointestinal symptoms of patients with irritable bowel syndrome. Middle East journal of digestive diseases 2019;11(4):211-7.

46. Farifteh S, Mohammadi-Aria A, Kiamanesh A, Mofid B. The impact of laughter yoga on the stress of cancer patients before chemotherapy. Iranian journal of cancer prevention 2014;7(4):179-83.
47. Kim SH, Kim YH, Kim HJ. Laughter and stress relief in cancer patients: a pilot study. Evidencebased complementary and alternative medicine 2015;2015. https://doi.org/10.1155/2015/864739

48. DeCaro DS, Brown JLC. Laughter yoga, adults living with Parkinson' s disease, and caregivers: A pilot study. Explore 2016;12(3):196-9.

49. Fujisawa A, Ota A, Matsunaga M, Li Y, Kakizaki $M$, Naito $H$, et al. Effect of laughter yoga on salivary cortisol and dehydroepiandrosterone among healthy university students: A randomized controlled trial. Complementary therapies in clinical practice 2018;32:6-11.

50. Tanaka A, Tokuda N, Ichihara K. Psychological and physiological effects of laughter yoga sessions in Japan: A pilot study. Nursing \& health sciences 2018;20(3):304-12.

51. Ozturk FO, Tezel A. Effect of laughter yoga on mental symptoms and salivary cortisol levels in first-year nursing students: A randomized controlled trial. International Journal of Nursing Practice 2021:e12924.

52. Supekar NR, Shimpi AP, Madane AV, Rairikar SA, Shyam AK, Sancheti PK. Role of laughter clubs in promotion of health in community (A case control study). Indian Journal of Physiotherapy and Occupational Therapy 2014;8(2):110-4. 